\title{
植物材料からの新しいポリウレタン
}

\author{
大妻女子大学 中 村 邦 雄 \\ 製品科学研究所 畠 山 兵 衛
}

\section{New Types of Polyurethanes from Plant Materials}

\author{
Kunio Nakamura \\ Otsuma Women's University \\ Hyoe Hatakeyama \\ Industrial Products Research Institute
}

\begin{abstract}
New types of polyurethanes were synthesized from kraft lignin, solvolysis lignin and wood meal by polymerization with polyethylene glycol (PEG) and diphenylmethane diisocyanate (MDI). The results obtained are as follows.

(1) Polyurethane films were made by solvent casting, and their tensile properties were measured. It was found that kraft and solvolysis lignins contributed effectively to an improvement in the mechanical properties of polyurethanes. Polyurethanes of considerable toughness were obtained, under specific conditions of the isocyanate/hydroxyl group ratio $(\mathrm{NCO} / \mathrm{OH})$ and also depending on either kraft or solvolysis lignin content. At high kraft and solvolysis contents, the obtained polyurethanes were hard and brittle, regardless of the $\mathrm{NCO} / \mathrm{OH}$ ratio used in the experiment.

(2) Polyurethane foams were synthesized from a three-component system consisting of PEG, MDI and kraft lignin. Polyurethane foams having kraft lignin contents of up to $40 \%$ and apparent densities ranging from 0.04 to $0.22 \mathrm{~g} / \mathrm{cm}^{3}$ were prepared by controlling the kraft lignin content, $\mathrm{NCO} / \mathrm{OH}$ ratio and water content. The compressive strength and elasticity of the polyurethane foams increased with increasing kraft lignin content and $\mathrm{NCO} / \mathrm{OH}$ ratio.

(3) Polyurethane films and foams, which were synthesized by using wood meal as a raw material, generally showed similar mechanical properties to those of polyurethanes which were synthesized from kraft and solvolysis lignins.
\end{abstract}

\section{1.はじめに}

日本の合成高分子の生産量は 1 千万トンを超え, 需

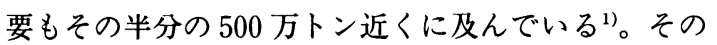
内ポリウレタン (PU) は約 25 万トンであり, 需要の $5 \%$ を占め年々増加の傾向にある。製品としては フォームタイプが最も多量に使用されエラストマー, 塗料, 接着剤, 纎維, 合成皮革等がそれに次いでいる。 ポリウレタンフォームは全 PU の $80 \%$ 近くを占め, 軟 質フォームが約 $70 \%$, 硬質フォームが約 $30 \%$ の割合で ある。その用途は多分野にわたり, 特に軟質フォーム は家具, 寝具, 自動車用に, 硬質フォームは断熱材,
建材等に用いられている。特に最近, PU は自動車分野 に多く使用され, 自動車に使われる全プラスチックの 中では一番多く $17 \%$ にんでいる ${ }^{1-3)}$ 。

PUはポリオールとイソシアネートの反応により得 られるが，一般的には三次元架橋結合を有する高分子 である。このPUの原材料であるポリオールは主とし てポリエーテルタイプが用いられ，ポリエステルポリ オールが少量使用されている。ジイソシアネートはト ルイレンジイソシアネート (TDI), ジフェニールメタ ンジイソシアネート (MDI), へキサメチレンジイソシ アネート (HMDI) 等が使用されている。これら純粋 なイソシアネートは毒性が強く, 粘度が低い等の欠点 
を持つ。そこで, この点をカバーするため最近ではオ リゴマー化して使用するのが一般的である。これらの PU 原料は, 汎用の高分子に比較して高価であり,これ に代わる安価な材料が手に入るならば利用範囲はさら に拡大されるものと考えられる。

一方, 全世界で植物資源に由来するバイオマスとし ての年間生産量は $2 \times 10^{11}$ トンといわれ，エネルギー 消費量の約 10 倍に相当し，この内の $90 \%$ は木材であ る。木材の主要構成成分はセルロース, へミセルロー ス, 及びリグニンであり，厳密には樹種により異なる が，それぞれ約 $45 \% ， 25 \%$ 及び $30 \%$ を占めている。セ ルロース及びへミセルロースは糖残基に結合した水酸 基を, リグニンはフェニルプロパン構造に結合した水 酸基を持ち，いずれも分子中に水酸基を有した高分子 であり，ポリオールとして考えることが可能である。

我々はこれまでに植物を起源にする材料を用いて工 業的な応用を考えてきた ${ }^{4-6)}$ 。例えば，リグニン分解物 を原料としてポリスチレン, ポリエステル, ポリエー テル誘導体を合成してその特性を検討した結果, 耐熱 性, 強度特性に優れた高分子材料が得られることが明 かとなった ${ }^{7-15)}$ 。また各種りグニン, 木粉及びセルロー スパウダーを用いて P Uを合成し, その特性を検討し これらの材料が十分に実用性あること等を明らかにし た16-19)。

ここではクラフトリグニン (KL), ソルボリシスリ グニン (SL), ユウカリリグニン (EL) 及び木粉を用 い,これらをポリオールとしてPUを合成し，その物 性を測定した結果について少し詳細に述べることにす る。特にリグニンの違いによる物性の特徴, 共通点, フィルムとフォームの構造の違いによる特幑等につい て記し, リグノセルロースの PU への応用の可能性に ついて検討する。

\section{2. リグニンからの $\mathbf{P U}$}

リグニンは木材の構成成分中で約 $30 \%$ も占めるに もかかわらず，これまで余り有効に利用されていな かった。例えばパルプ生産工程中に副産物として大量 に得られるリグニンの主要な用途は燃料であり, 僅か の量が加工されて分散剤あるいは乳化安定剤として利 用されているに過ぎない。そこで我々はこのリグニン の有効利用法の一環として, 適度な粘性を持つポリ オールに变換し PUの調製を試みた。

2.1 クラフトリグン (KL) からの PU フィルム KLを用いて PUを調製しようという試みは W. G. Glasserのグループによって 1975 年頃から行われて きた 20-24)。この場合, リグニンは化学的に修飾されカ
ルボキシレート化，ヒドロキシプロピル化することで ポリオールとして扱い易いように工夫されている。し かしリグニンの化学修飾にはかなりの手間とコストが かかり実用的にはほとんど採用されずに今日に至って いる。我々はこの点を考虑してリグニンの化学的修飾 を行わずに，ポリオールを調製して PUの原料として 使用することを検討した。

一般的にはPUは発泡したフォームタイプが最も多 く利用されている。またエラストマー, 塗料, 接着剤 等として用いる場合もある。しかし研究を進める上で 扱い易く, 情報量も多く得られるという利点があるこ とを考虑して，まず PUフィルムを調製した。

$\mathrm{KL}$ から PU フィルムの調製は, 溶媒を用いて KL を液化しイソシアネートと反応させて PU を得る方法 を試みた。工業的利用を考虑した場合には，分別せず にKL を使用することも可能であるが，実験上の精確 性を考虑して分子量分別した KL を用いた。中間領域 の分子量を有する KL をポリプロピレンオキサイド ベースのトリオールに混合し, ジフェニールメタンジ イソシアネート (MDI) とテトラヒドロフラン (THF) 中で $20^{\circ} \mathrm{C}, 8$ 時間反応させた。得られた反応液を金属 枠を付けた水平のガラス板上に注ぎ，1昼夜以上ドラ フト中に放置してフィルムを得た。得られた PUは THF 溶媒中で均一反応が行われるため, 光学的に透 明で均一な褐色のフィルムであった。またかなり剛直 なものからゴム状の弾性に富む PU まで得られた。こ の方法による PU の調製は, 反応後製膜するときに溶 媒を蒸発させなければならないことが欠点である。

図 1 (a)に PUの架橋密度 $(\rho)$ と $\mathrm{NCO} / \mathrm{OH}$ 比 (イ ソシアネート/ポリオール比）の関係を，（b ）に架橋 密度と熱処理時間の関係を示す ${ }^{19)}$ 。PU の物性は三次 元ポリマーであるから架橋密度に強く依存することは 明かであるが, 図1(a)に示すように架橋密度は $\mathrm{NCO} / \mathrm{OH}$ 比の増加と共に増加し, イソシアネートに よりポリオールが架橋されPUが形成されていくこと が分かる。また PU 中の KL の含有量の増加も架橋密 度の増加を促進していることが明かとなった。さらに 図 1 (b)に示すようにPU を成形後に熱処理する場合, 架橋密度はその熱処理温度及び時間の増加と共に増加 することが分かった。このことは成形後の PU の物性 が多少経時変化を起こし, 熱処理により固定されるこ とを示唆している。

図 2 及び 3 に $\mathrm{PU}$ の破断強度及びヤング率と $\mathrm{KL}$ 含 有量の関係を示す ${ }^{19)}$ 。強度及びヤング率はいずれも図 に示すように KL 含有量の高い PU ほど高くなり, あ る量以上になると一定になる傾向がみられた。また 
(a)

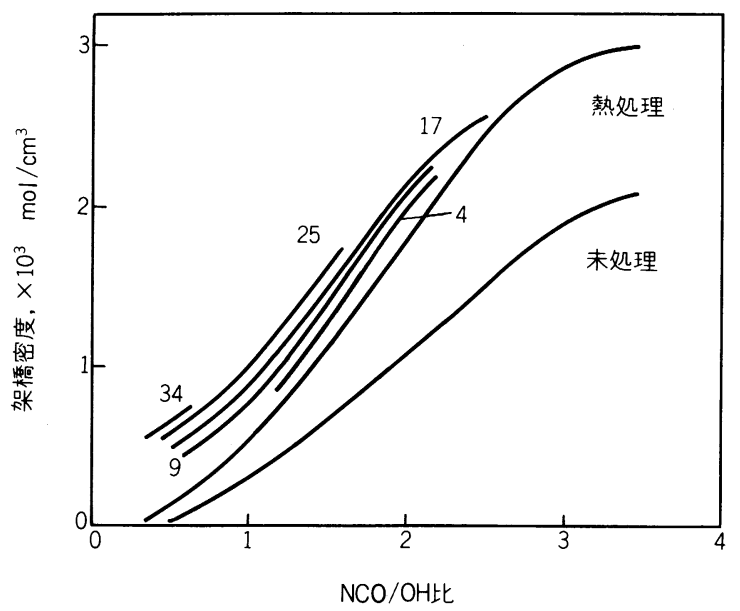

(b)

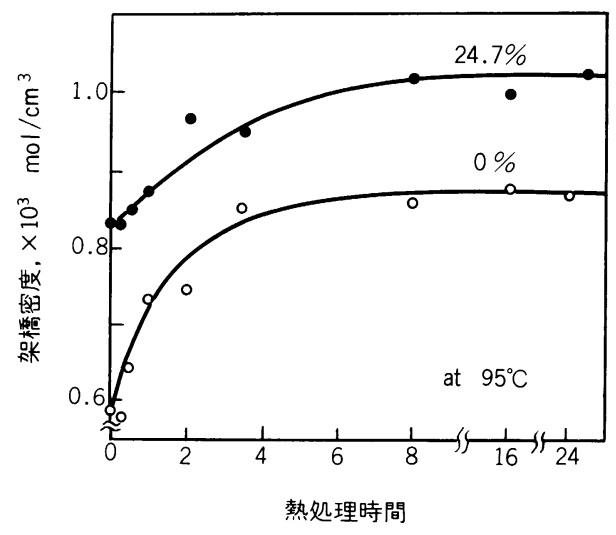

図 1 (a) 架橋密度と $\mathrm{NCO} / \mathrm{OH}$ 比の関係

困中の数字はクラフトリグニン含有率を示す

(b) 架橋密度と熱処理時間の関係

図中の数字はクラフトリグニン含有率を示す

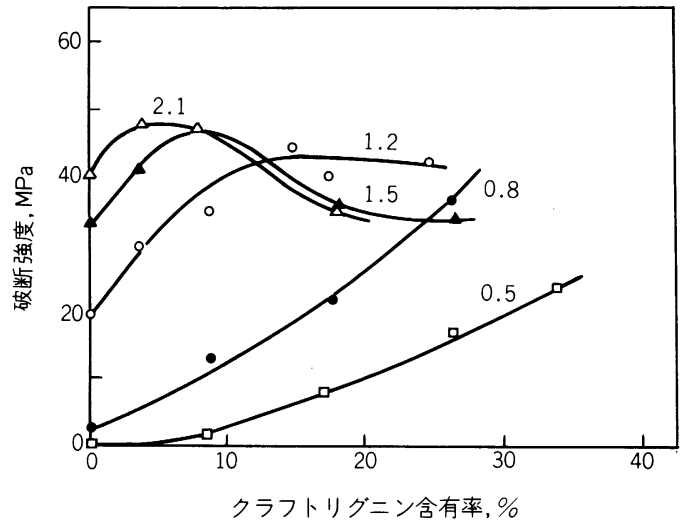

図 2 破断強度とクラフトリグニン含有率の関係 図中の数字は $\mathrm{NCO} / \mathrm{OH}$ 比を示す

$\mathrm{NCO} / \mathrm{OH}$ 比の増加と共に強度及びヤング率が増加す ることも明かである。このことはイソシアネートが架 橋剤として反応し, 架橋密度を増加させることはもち ろんのこと, リグニンが構造中にベンゼン環を持つた めPU中でハードゼグメントとして働き，なおかつ架 橋効果もあるため強度が増加するものと考えられる。 特に $\mathrm{NCO} / \mathrm{OH}$ 比が高く, かつ $\mathrm{KL}$ 含量の高い試料は 相当に脆く，伸度も小さく脆性破壊を起こすため強度 の増加が認められなかったものと考えられる。

以上述べたように，KLから調製した $\mathrm{PU}$ はソフト タイプからハードタイプまで $\mathrm{NCO} / \mathrm{OH}$ 比及び $\mathrm{KL}$ 含 有量を制御することにより得られることが明かとなっ

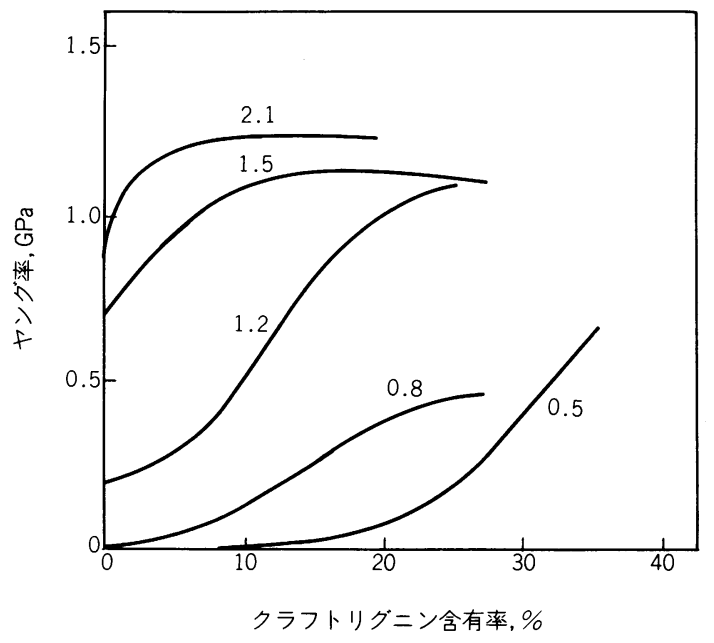

図 3 ヤング率とクラフトリグニン含有率の関係 困中の数字は $\mathrm{NCO} / \mathrm{OH}$ 比を示す

た。

2.2 ソルボリシスリグニン (SL) からの $\mathbf{P U}$ フィルム

我が国で開発されたクレゾール一水系溶媒によるソ ルボリシスパルプ化法 ${ }^{25-27)}$ 副産物として得られる SL を原料として PU フィルムを調製した。すなわち, $\mathrm{SL}$ と MDI THF 中で反応させプレポリマーを得 た。次いでこのプレポリマーにPEGを加えてさらに 一定時間反応させ, SL-MDI-PEG 形の PU を調製し た。筆者らの実験結果に寄れば反応温度 $60^{\circ} \mathrm{C}$, 全反応 
時間 2 時間で得られるポリウレタンシートの引張り強 度が最大であった。

さらに, 架橋密度に及ほす $\mathrm{NCO} / \mathrm{OH}$ 比と PEG の 分子量の影響を調べたところ, 架橋密度は KL の場合 と同様に, $\mathrm{NCO} / \mathrm{OH}$ 比及び $\mathrm{SL}$ 含有量に比例して増 加することが明かとなった。一方, 架橋密度に及ほす PEG 分子量の影響は余り大きくなかった。

$\mathrm{NCO} / \mathrm{OH}$ 比の $\mathrm{PU}$ の強伸度特性に対する影響を調 べたところ，ソフトセグメントである PEG を含まな いSL-MDI 系の PU の強度は $80 \mathrm{MPa}$ とかなり高く, 一般のエンジニアリングプラスチックに比較しても劣 らないことが分かった。例えば，代表的なエンジニア リングプラスチックであるポリスルホンで $70 \mathrm{MPa}$, ポリカーボネートで $65 \mathrm{MPa}$ 程度であるから, SLMDI 系 PU の強度はかなり満足すべき值であると見 て良かろう。SL及び MDI 共にハードセグメントとし て作用するため, 得られた PU の弾性率は高く, 伸度 は小さくなる。また強伸度特性に及ほす $\mathrm{NCO} / \mathrm{OH}$ 比 の影響は余り大きくない。しかし, SL を $20 \%$ 含有する $\mathrm{PU}$ では $\mathrm{NCO} / \mathrm{OH}$ 比の增加と共に強度及びヤング率 が顕著に増加し, $\mathrm{NCO} / \mathrm{OH}$ 比 1.6 で破断強度が 50 $\mathrm{MPa}$ 程度となり, 実用的にも十分な強度が得られる。 一方, SL を全く含まない PEG-MDI 系の PUでは, 強 度が著しく低く, $\mathrm{NCO} / \mathrm{OH}$ 比が 1.6 の時に $20 \mathrm{MPa}$ 弱程度である。このように SL をたかだか $20 \%$ 含ませ るだけで沉用の高分子に近い強度が得られることは興 味深い。

図 4 にSL 含有量と強度の関係を示す。ヤング率も 強度とほほ同様の変化を示すが, 強度はSL 含有量の 増加と共に増加し, SL が $40 \%$ 以上含む PU の強度特 性は一般のエンプラに近い值であると考えられる。こ こで調製した PUは $\mathrm{NCO} / \mathrm{OH}$ 比が一定であるから， SL含有量の低い PUは逆に PEG が多いことを意味 するが, PEG がソフトセグメントとして働くため強 度は PEGの増加と共に下がり, 伸度は上がることが 分かる。

図 5 に PU 中の PEG 含有量と強度及び伸度の関係 を示す。困から明かなようにPUの強度はPEGの含 有量の増加と共に減少し, ハードな PUからソフトな $\mathrm{PU}$ 一変化していくのが分かる。また伸度は PEG 含量 $45 \%$ 点に極大値を持ち, その前後では伸度は小さく なることが分かる。この結果は SL 及び MDI がハード セグメントとして PU 中で作用し, PEGだけがソフ トセグメントになることを意味している。このように SL-MDI-PEG 系の PU の物性は, PEGの量により ソフトなものからハードなものまでコントロール出来

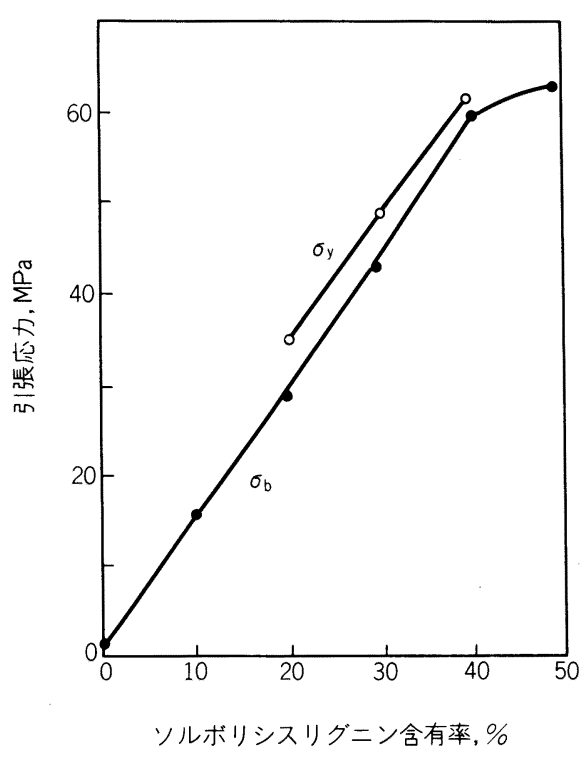

図 4 引張応力とソルボリシスリグニン含有率 の関係

$\sigma_{\mathrm{y}}$ は降状応力, $\sigma_{\mathrm{b}}$ は破断強度

ソルボルシスリグニントイソシアネート含有率, \%

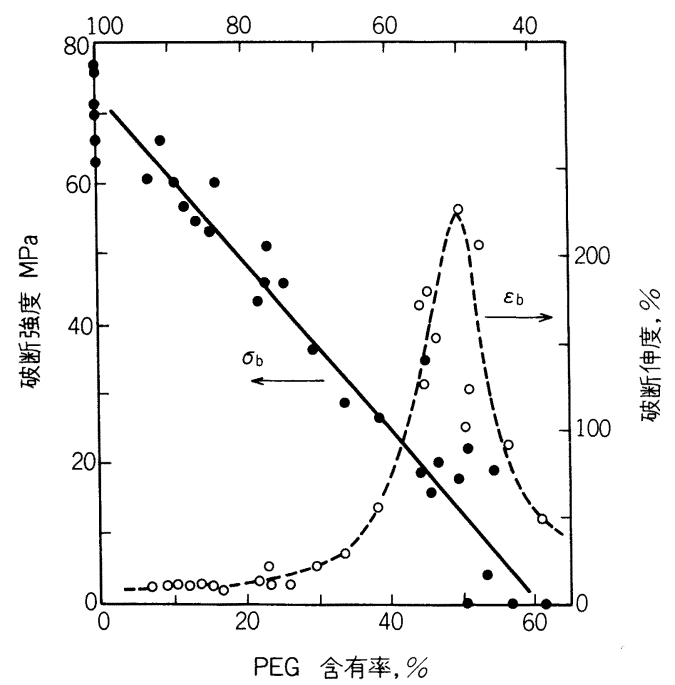

図 5 破断強度 $\left(\sigma_{\mathrm{b}}\right)$ 及び伸度 $\left(\varepsilon_{\mathrm{b}}\right)$ とポリエチレ ングリコール $(\mathrm{PEG})$ 含有率の関係

ることが分かる。さらに KL 及び SL から調製した PU フィルムの機械的性質は, リグニンの種類によら ずリグニン含有量に強く依存することが明かである。

\section{$2.3 \mathrm{KL}$ からの PU フォーム}

PU はフォームタイプとして車両, 家具, 機器, 建材 等に利用する場合が最も多く，80\%以上が硬質及び軟 
質フォームとして利用されている。それ故，実用性を 議論する場合は, フォームとしての利用が可能である かどうかが非常に重要になって来る。そこで我々はリ グニン及び木粉を用いて PU フォームの調製を試みた。 フォームの場合は, フィルムを調製したように $\mathrm{THF}$ 等の溶媒を用いる方法ではフォーム中のセルが 破壊され，きめのこまかい独立気泡は得られず調製が 困難であった。そこで，一般的な有機溶媒によらない リグニンの液化の方法として，ポリエチレングリコー ル $(\mathrm{PEG})$ やポリプロピレングリコール $(\mathrm{PPG})$ への リグニンの溶解に注目した。PEG やPPG は通常の PU フォームのポリオールとして使用されているため, これらの混入は PU の製造に何等の支障を来すもので はない。そこで, PEGの分子量 400 を用いてリグニン を溶解させポリオールとした。具体的にはリグニン含 有量を制御するため, PEG 400 に一定重量の KL を混 合擋找し $60^{\circ} \mathrm{C}$ で約 1 時間溶解させた。分子量が高い PEG $(\mathrm{Mw}=1,000)$ でも高温度 $\left(60-100^{\circ} \mathrm{C}\right)$ にするこ とにより KL は溶解させることが可能であった。また $\mathrm{PPG}$ も同様に均一な KL を含有するポリオールと なった。

$\mathrm{PU}$ フォームの調製は，一定量の上記ポリオールに 一定量の整泡剂 (シリコーン系界面活性剤), 触媒 (有 機スズ化合物）及び発泡剤としての水（工業的にはフ レオンガス）を加え，良く擋找し（擋拌機を使用し 7,000-10,000 rpm, 約 5 分), 別に一定量の MDI を 科量しておき，擋找しながらポリオール中に注ぎ発泡 してくるまで擋找を続ける。反応が始まり発泡してき たら擋拌機から反応容器を取り除き, PU フォームが 成長して来るのを待つ。得られた PUフォームは均一 な気泡を持ち, 密度は 0.03 から $0.15 \mathrm{~g} / \mathrm{cm}^{3}$ であり, 色はリグニン量の増加と共に褐色が強くなる傾向で あった。ちなみに市販の PU フォームの密度は約 0.03 $-0.06 \mathrm{~g} / \mathrm{cm}^{3}$ である。

図6にPUの密度 $(\rho)$ と圧縮強度 $(\sigma)$ の関係を示 す $^{18)}$ 。この図から分かるように, 強度は密度の増加と共 に直線的に増加しほぼ比例関係にあることが分かる。 これはPU フォーム中の密度の増加は空陌率の減少を 意味し, 強度を分担する PU 固体部分が増加したため と考えられる。換言すれば，PU フォーム中のセルの 肉厚が増加したためと考えられる。このように $\mathrm{PU}$ フォームの強度特性は, フィルムの場合に強く影響を

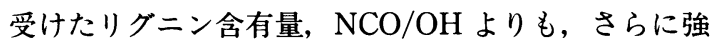
く密度が影響することが明かとなった。

図 7 に KL 含有量と強度 $(\sigma)$ 及びヤング率 $(\mathrm{E})$ の 関係を示す18)。但し先に述べたように密度 $(\rho)$ の影響

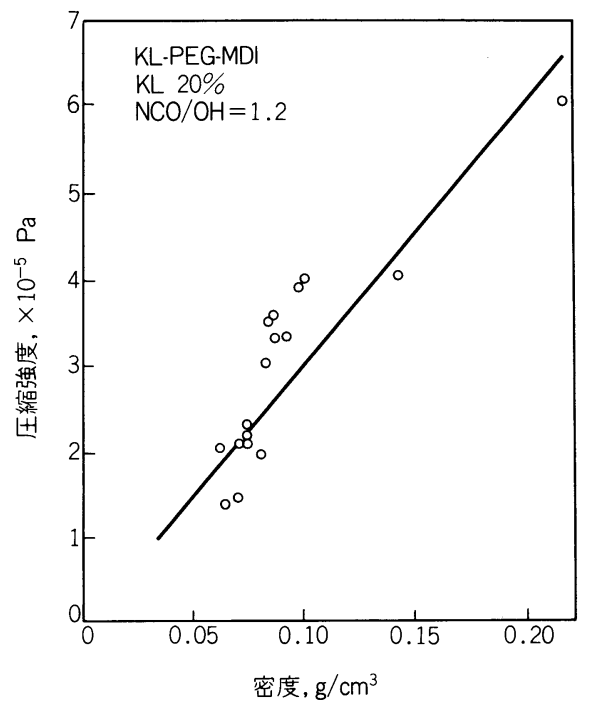

図 6 圧縮強度と密度の関係

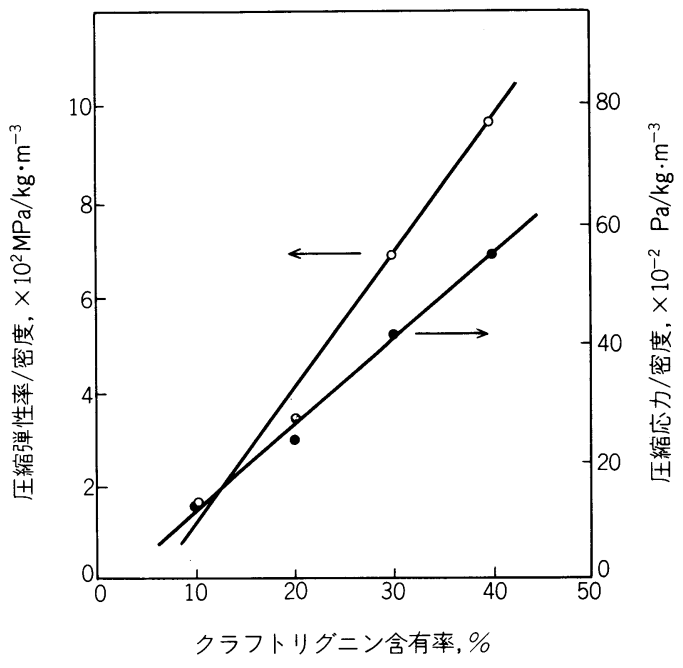

図 7 圧縮弾性率/密度及び圧縮応力／密度とクラ フトリグニン含有率の関係

が非常に大きいので密度でこれらの值を割った $\sigma / \rho$, $\mathrm{E} / \rho$ の值で示した。図から分かるように強度及びヤン グ率は KL の増加と共に直線的に増加し, $\mathrm{KL}$ が $\mathrm{PU}$ 中でハードセグメントとして働いていることが分かる。

$\mathrm{KL}$ を含むPUフォームの系おいても, 強度は $\mathrm{NCO} / \mathrm{OH}$ 比の増加と共に増加する。これはイソシア ネートが架橋密度を増加させ, PUの三次元化が進行 するためと考えられる。またイソシアネートがリグニ ン同様に PU 中でハードセグメントとして働くことが 強度の増加に寄与していると考えられる。

以上のようにクラフトリグニン $(\mathrm{KL})$ を用いて $\mathrm{PU}$ 
フォームを調製することが可能であり，その機械的性 質は, フォームの密度に強く依存し, リグニン含有量 に比例して向上することが分かった。特にKLを $40 \%$ 含む PU フォームの圧縮強度は $0.7 \mathrm{MPa}$ 近く, 市販の $\mathrm{PU}$ フォームより高くなり, リグニンの使用により強 度面での改良が著しいことが明かである。

\section{3. 木粉からの PU}

木粉からのPUの調製は, リグニンの場合とは異な り,ポリオールの調製が少し複雑である。即ち, 木粉 を液化するためには, 通常 $200^{\circ} \mathrm{C}$ 以上の高温で加圧条 件下で反応させなければならない。液化した木粉中に はかなりの量の水分が含まれるため, 実験室的には $120^{\circ} \mathrm{C}$ で 1 昼夜程度の脱水処理が必要である。得られた ポリオールを原料として MDI を用いて, KLから $\mathrm{PU}$ フォームを調製したとのとほほ同様の条件で PU フォームを調製し得る。

図 8 に木粉から調製したポリオール (ウッドポリ オール）の量と得られた PUの密度及び圧縮強度の関 係を示す。四から明らかなように密度及び強度はウッ ドポリオールの増加と共に直線的に増加するのが分か る。このことからウッドポリオールが PU 中でハード セグメントとして働き, その増加により PU の強度が 增加しているのが分かる。ヤング率も同様の変化を示 した。これはリグニンの結果と類似しており, ウッド ポリオールもリグニンポリオール同様の性質を有して いると考えられる。

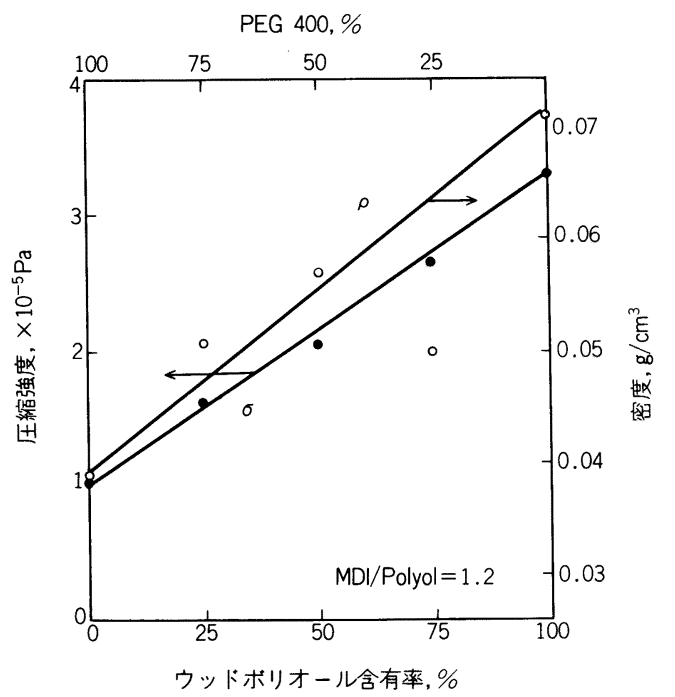

図 8 圧縮強度及び密度とウッドポリオール含有率 の関係

$\rho$ は密度, $\sigma$ は強度を示す
$\mathrm{PU}$ の強度及び密度と $\mathrm{MDI} /$ ポリオール比の関係を 調べると, 強度は MDI/ポリオール比の増加と共に増 加するが, 密度は逆に減少することが分かる。MDI/ Polyol 比が約 1.0 までの低い範囲では架橋密度が低 く, 得られたPUはかなりソフトで弾力性に富んでい た。さらにPUの寸法安定性が悪く, 体積収縮が時間 と共に進行した。1.0 以上になると強度も増し, 気泡 も均一化され次第に PU の物性は安定して来ることが 分かった。このように密度が減少するにもかかわらず 強度が増加するのは密度の効果よりも架橋密度の効果 の方が強く現れたためと考えられる。この傾向は $\mathrm{KL}$ から調製したPU フォームの結果とよく一致するが, ユーカリリグニンからの PU フォームの場合は逆の関 係になり，リグニンの種類により得られる PU の性質 が異なって来ることが示唆された。

また PU の強度及び密度に及ほす発泡㓮として用い た水の量の影響を検討したところ，低水分率の範囲で は強度は水分率の増加と共に減少する傾向が認められ た。しかし水の量が更に増加すると極小值をとり強度, 密度共に増加することが分かった。これは極小点以上 では水の量が過剩であり，一度できた気泡をつぶして 再び気泡を作るという繰り返しが行われ，最終的には 密度の高い肉の厚いセルとして安定化するためと考え られる。ヤング率の測定結果からも同様の傾向が認め られた。さらに木粉を溶解させるのに用いたPEGの 分子量と得られた PU の強度及び密度の関係を検討し たところ, PEGの分子量の増加と共に密度は減少し, 強度も 600 までは減少した。しかし 1,000 では密度は 減少するにも拘らず，強度は多少増加することが分 かった。このことから, PEGの分子量はPU の物性に ある程度の影響及ほすと推定される。

\section{4. おわりに}

以上述べたように, リグニンおよび木粉のいずれも ポリオール化することにより, PUの原料となり, 調製 した PU の物性はこのポリオールの含有量に強く依存 する。ポリオールの含有量が高いと, PU の強度及び弾 性率はエンジニアリングプラスチックに匹敵するくら いの高さを示すようになる。またPU フォームの場合 には, リグニン含有量の高い硬質フォームの方が経済 的メリットが大きいと考えられる。いずれにせよ，実 用面での検討は今後に残された課題であり, 研究次第 でいろいろと面白い用途が見いだされると期待される。

\section{謝 辞}

本研究を行うにあたり, 貴重な試料を御恵与いただ いた日本紙パルプ研究所, 三木産業ならびにスウェー 
デン紙パルプ研究所に深く感謝する。

\section{文献}

1）高分子工業年鑑，高分子，6月号増刊，高分子学 会 (1989)

2）ポリウレタン樹脂ハンドブック，岩田敬治，日刊 工業新聞社 (1987)

3）ポリウレタン樹脂製品，日本ウレタン工業協会 (1986)

4）畠山兵衛, 纎維と工業, $38, P-72$ (1982)

5）畠山兵衛，高分子，36，426 (1987)

6) 畠山兵衛, 化学と工業, 40，941 (1987)

7) K. Nakamura, T. Hatakeyama and H. Hatakeyama, Polymer, 22, 473 (1981)

8）中村邦雄, 畠山立子, 畠山兵衛, 高分子論文集, 12, 765 (1982)

9) K. Nakamura, T. Hatakeyama and H. Hatakeyama, Polymer J., 18, 219 (1986)

10）広瀬重雄, 畠山立子, 畠山兵衛, 高分子論文集, 39, 733 (1982)

11）広瀬重雄, 畠山兵衛, 畠山立子, 瀻維学会誌, 42, $\mathrm{T}-49$ (1986)

12）広瀬重雄, 畠山兵衛, 畠山立子, 繊維学会誌, 39 , T-496 (1983)

13）広瀬重雄, 畠山兵衛, 畠山立子, 繊維学会誌, 41 , $\mathrm{T}-432$ (1985)

14）広瀬重雄, 中村邦雄, 畠山立子, 畠山兵衛, 繊維 学会誌，43，595 (1987)

15) H. Hatakeyama, S. Hirose and T. Hatakeyama, ACS Symposium Series 397, 205 (1989)
16) S. Yano, S. Hirose and H. Hatakeyama, in "Wood Processing and Utilization" (J. F. Kennedy et al. eds.), Ellis Horwood, Chichester, 1989, p.263

17) S. Hirose, S. Yano, T. Hatakeyama, and H. Hatakeyama, ACS Symposium Series 397, 382 (1989)

18) K. Nakamura, R. Mörck, A. Reimann, K. Kringstad and H. Hatakeyama, in "Wood Processing and Utilization" (J. F. Kennedy et al. eds.), Ellis Horwood, Chichester, 1989, p.175

19) H. Yoshida, R. Morck, K. Kringstad and H. Hatakeyama, J. Appl. Polym. Sci., 34, 1187 (1987)

20) V. P. Saraf and W. G. Glasser, J. Appl. Polym. Sci., 29, 1831 (1984)

21) T. G. Rials and W. G. Glasser, Holzforschung, 38, 191 (1984)

22) V. P. Saraf, W. G. Glasser, G. L. Wilkes and J. E. McGrath, J. Appl. Polym. Sci., 30, 2207 (1985)

23) V. P. Saraf, W. G. Glasser and G. L. Wilkes, J. Appl. Polym. Sci., 30, 3809 (1985)

24) O. H. H. Hsu and W. G. Glasser, Appl. Polym. Symp., 28, 297 (1975)

25）佐野嘉拓, 榊原 彰, 木材学会誌, 30, 569(1984)

26）佐野嘉拓，榊原 彰，笹谷宣志，木材学会誌，30, 857 (1984)

27）佐野嘉拓, 柇原 彰, 木材学会誌, 31, 109(1985) 